\title{
HOMER3 Gene
}

National Cancer Institute

\section{Source}

National Cancer Institute. HOMER3 Gene. NCI Thesaurus. Code C104569.

This gene plays a role in the structure of the postsynaptic density. 